\title{
The Meaning Transformation of Business Success among Muslim Women Entrepreneurs in Surakarta Region
}

\author{
Dwi Prasetyani ${ }^{1, *}$, Amelia Choya Tia Rosalia ${ }^{2}$, Ali Zainal Abidin ${ }^{3}$
}

\author{
${ }^{1,2}$ Department of Development Economics, Faculty of Economic and Business, Universitas Sebelas Maret Surakarta, Indonesia \\ ${ }^{3}$ Department of Development Economics, Faculty of Economic and Business, Universitas Muhammadiyah Surakarta, \\ Indonesia \\ *Corresponding author. Email: dwiprasetyani_fe@staff.uns.ac.id
}

\begin{abstract}
Entrepreneurship has proven to be a sector that can provide welfare for business actors. This situation encourages numerous parties to become entrepreneurs, including Muslim women. This research explained Muslim women entrepreneurs' backgrounds, processes, efforts, and achievements in their business journeys. The phenomenological study was implemented as the research method, while the purposive sampling technique and semi-structured interviews were employed to obtain the data. The results showed that Muslim entrepreneurs had undergone a transformation in interpreting the business achievements they have acquired. This change resulted from several factors, including personal experience, self-disclosure, environment, and access to information. This transformation then manifested in economic and non-economic aspects, where Muslim women entrepreneurs gradually preferred business blessings rather than mere profit. The business objectives also prioritized benefit, almsgiving, and resolve conflicts by believing in Allah SWT. This transformation was the beginning of their new journey in achieving prosperity in this world and the hereafter.
\end{abstract}

Keywords: transformation, business success, Muslim women entrepreneurs, entrepreneurship.

\section{INTRODUCTION}

In recent years, women entrepreneurs have received greater attention among researchers, policymakers, and society (Ramadani, 2015). Women's participation in productive activities has increased from year to year (Shastri \& Rao, 2014). Women entrepreneurs in Indonesia play an essential role in running micro, small, and medium enterprises. They have a significant role as a driver of the Indonesian economy in general and for improving family welfare in particular (Ismail, 2014). Several studies and programs claim that the welfare contribution resulting from women's entrepreneurship is higher than that generated from men's activities (Minniti, 2010). Unfortunately, the number of women entrepreneurs is much lower than that of men. Although the government and all have given much attention, the influence of gender differences in entrepreneurial behavior remains.

Seeing the prominent role of women entrepreneurs in the Indonesian economy in general, and in particular the significant role in improving family welfare, this study examined the involvement of women in the business sector in the entrepreneurial context. Entrepreneurship is a generative and transformative process of changing conventions in which personal/social histories, assets, technologies, and trading activities are collected in organizational forms (Clarke \& Holt, 2019). Entrepreneurship is performed by empowering existing resources in the surrounding environment. How the entrepreneur frames this process, and, in turn, is governed by this process, constitutes the entrepreneurial experience.

Entrepreneurs who love their work are likely to be more successful than others. It is due to the positive impact it brings to the surrounding environment. Success in business lies not only in the entrepreneur but also in terms of the people around the entrepreneur, i.e., the employees and customers (Chin et al., 2012). The ability to manage these people plays an essential role in the success of a business venture. In today's business environment, knowledge-intensive management of workers is critical to maintaining a company's competitive advantage (Salas-Vallina et al., 2018). Happiness at work is a research topic that is becoming increasingly crucial. Changes in mindset and perspective that were previously oriented to profit only have now turned into fulfilling spiritual needs through business activities. This behavior change is hereinafter referred to as behavioral transformation.

Muro \& Turner (2018) suggested the pursuit of opportunities through analytical conceptualization by framing a new concept called the "Opportunity Project," which is described as a unique transformation of business models to transform opportunities from a state of possibility to a favorable state of change. Opportunities in their development are subject to milestones that change the course of their development. The availability of information and experience supports behavioral transformation. Access to information can be done through various instruments, including mass media, electronic media, or Islamic religious studies. When 
someone gains such access, he/she has received additional lessons so that the perception of transformation is more significant than entrepreneurs who do not have access to information. The behavior of Muslim women entrepreneurs in performing business activities and achieving business success is also based on spiritual values. It is formed through the transformation that Muslim women entrepreneurs perform their roles as economic actors. The decisions taken by Muslim women entrepreneurs are not always in line with the behavior of producers in general. It is because the decisions made are based on a spiritual and experiential component.

Entrepreneurial experience can occur through experiential learning and practice through business creation, student consulting activities, and educational simulations (Newbery et al., 2018). Experience indicates how much effort and problems have been encountered and resolved. The more experience passed, the better the quality of the individual entrepreneur (Clarke \& Holt, 2019).

\section{THEORETICAL FRAMEWORK AND HYPOTHESES}

If we believe that women's entrepreneurship is essential for development, then understanding its causes and motivations is also crucial, especially since the percentage of women engaged in entrepreneurship worldwide is much lower than the percentage of men (Minniti, 2010). The main factors identified as driving women to leave work for business ownership are the need to achieve personal growth, independence, and economic outcomes (Xavier et al., 2012). Passion for business, listening and communication skills, and self-discipline are among the most common personal skills. In the context of social entrepreneurship, women are more suitable to lead social enterprises. According to the utility perspective, social support is more useful when used to a greater extent (Kaciak \& Welsh, 2020). Business practitioners also agree that entrepreneurs who are successful in growing and developing their companies are more open (Slavec et al., 2017). Although openness in entrepreneurship has been recognized as a leading force for entrepreneurs, good conceptualization and empirical validation of entrepreneurial openness are lacking.

The frequently cited causes of women setting up smaller firms are, on the one hand, the greater difficulty they face in finding resources to finance their projects, and on the other hand, a lack of specialized knowledge to perform the task successfully. These reasons relate to discrimination against women in the labor market (Akehurst et al., 2012). There is also greater job insecurity as women are employed more than men under permanent seasonal contracts employment contracts typical in fieldwork and tourism while men are responsible for most of the remaining types of contracts (Alonso \& Trillo, 2014). To survive and remain profitable in the existing market, women entrepreneurs can perform well by differentiating themselves from others through innovation. Innovation and entrepreneurship have an impact on performance, and innovation acts as a mediator between the two. Therefore, women entrepreneurs should strive to improve their performance by focusing more on traits such as risk-taking and the need for achievement (Zeb \& Ihsan, 2020).

Richard Cantillon introduced the concept of entrepreneurship in 1775, which was later concerned by Ricardo, Adam Smith, and Mill (Zeb \& Ihsan, 2020). Entrepreneurship plays a vital role in lifting the economies of developing countries. Entrepreneurship is considered an essential driver of a country's economic growth and development as it helps create job opportunities, raise living standards, and reduce poverty (Nasir \& Iqbal, 2019). The concept of women's entrepreneurship is multidisciplinary, including economic, psychological, social, and cultural characteristics and the environment (Halim \& Razak, 2014). Interaction and social involvement between individuals are related to the concept of social capital. Social capital has contributed to the paradox of happiness in developed countries (Srensen, 2021).

The main result is that women entrepreneurs are primarily motivated by social goals closely related to them. Compared to male entrepreneurs, they are less influenced by external factors (such as finances) and more connected to their causes (Rosca et al., 2020). The behavior of Muslim women entrepreneurs that appear on the surface, for example, can be understood and explained if efforts to understand these behaviors can reveal what is hidden and what underlies their activities in running their business. What underlies them in determining the meaning of the success of their business may be different from the others. Interpreting the success factors of women entrepreneurs is a critical academic and managerial issue (Lee, 2015). In the process of business activities performed by women entrepreneurs, happiness, in the end, is the key. Individual happiness varies; among other things, the sentiment in the financial markets and volatile times are also, on average, unpleasant times (Bystrom, 2020). Happiness is balance in performing roles in life. Nothing is left or forgotten. Everything goes hand in hand, balanced and in harmony with both world and hereafter activities. Happiness is a feeling that describes the absence of fear and worry as a form of submission to Allah SWT.

\section{RESEARCH METHOD}

This study used a qualitative approach. This approach can explain the symptoms as experienced by the subject so that an appropriate portrait can be obtained and not merely a forced conclusion, according to the researcher. A qualitative approach can be used to observe the reality that is not just an outcome but how the process takes place and other realities that surround the process. Qualitative research is research conducted to uncover and understand social problems using words obtained from the situation experienced.

The qualitative approach was chosen because it can describe the conditions and activities that occur with the research subjects in line with the existing reality. Therefore, the data and research results are not in the form of calculations or statistical results but in the form of words and symbols that can be a consideration (Strauss and Corbin, 2003). This study used primary data from selected informants. Primary data 
were obtained through an unstructured in-depth interview process. Four informants have been determined using the purposive sampling method. The criteria for choosing the informants are Muslim women entrepreneurs, live in Surakarta, have business stability for three years or more, have children and husbands, join business organizations, and are eager to develop their businesses. The data obtained from four informants were considered sufficient to answer all the existing research questions. Meanwhile, the analytical method used was the phenomenological method.

According to Creswell (2010), the phenomenological approach is a research strategy by identifying one's phenomenon experience. This method prioritizes patterns and relationships of meaning from certain events. Hence, the results of the research produced will describe the whole phenomenon based on the situation and the actors' point of view. All data will be reduced, presented, and concluded based on the patterns and meanings formed.

\section{DATA ANALYSIS AND DISCUSSION}

Entrepreneurs' behavior will not be detached from the state of the economic, political, and social environment that surrounds the business. Furthermore, the entrepreneurs' response in dealing with the business scope is influenced by the values and norms held or applied in their society. In line with the level of knowledge and level of understanding, adherents of a religion will try their best to realize the teachings of that religion in their daily social behavior. The internalization of religious values is strongly influenced by various factors, both from one's background as an individual and social unit from one place to another.

In the case of informant 1 , a textile, garment, and advertising entrepreneur, she is quite successful in Surakarta. In managing her business, she continually emphasized the belief that work is for herself and her family. Her excellent work ethic forced her to leave his husband and children often. Economic motives were the main reason she joined the public sector. Her experience as a negotiator and a good business manager later shaped her character as she was today. She was grateful for the massive profits she made by performing the pilgrimage. Furthermore, she also habituated herself with sharing with others.

In the case of informant 2 , based on interview quotes, she initially wanted to become a successful businessman in the material sector. One of which was to become a drop shipper because of the ease of the mechanism. In developing her business, she constantly prioritized the quality of her products. The goal that would be achieved with her potential is that there are still opportunities to maximize potential. Furthermore, in the case of Informant 3, she is a Muslim businesswoman engaged in the culinary sector with a distinctive culinary. She continuously emphasized four issues in managing her business activities, i.e., "planning, actuating, controlling, evaluating" or planning, implementation, supervision, and evaluation. Management is the key to implementing her culinary business to become what it is today. Even though she had experienced ups and downs several times, she never forgot that everything that Allah SWT has given to her must be grateful for.

Informant 4, a Muslim businesswoman who runs in the culinary field, cooperated with her husband in managing her business. Since starting this business in 2010, they have sacrificed many materials, energy, and time. Even though she was busy with her business activities, she did not forget her dual responsibility as a mother to her children. While starting this business, she realized that her children received less attention from her and her husband. Thus, she had to make some adjustments to keep her business and family relationships running as expected. The sacrifice finally paid off. The culinary business is growing.

In the case of women entrepreneurs in Surakarta, there is a change in the behavior patterns of entrepreneurs in responding to business and their status as a woman. It is stated by two out of four informants who admitted that differences occurred in themselves, their families, and their respective businesses. These changes are fundamental because these changes are based on individual experience. This kind of pattern change can be called a transformation, where in the case is Muslim women entrepreneurs in Surakarta. The transformation that occurred is a transformation in behavior.

This behavioral transformation did not occur immediately but occurred gradually. The stages of behavior transformation go through several phases, i.e., the internalization phase or the introduction of Islamic values, then the understanding phase, the implementation phase, and finally the behavior transformation phase. A woman entrepreneur who undergoes a behavioral transformation means that she experiences a change in her behavior, where this new behavior will be based on the teachings of Islam. This behavioral transformation can occur in several business sectors, such as functions, objectives, and methods. The form of behavioral transformation can also differ from one another, depending on the ability of women entrepreneurs to understand the meaning and significance of the teachings of success they receive, especially in the business field. Behavioral changes can occur suddenly or even proceed depending on individual understanding. Entrepreneurs in Surakarta who experience a behavioral transformation can affect the surrounding environment. So, if this continues to happen, it is not impossible that all female entrepreneurs in Surakarta will also experience the same behavioral transformation.

Women entrepreneurs who undergo behavioral transformation realize that religious teachings are the main foundation in their daily lives, including business. However, other forms such as instinct and compassion then emerge without the need to be based on the practice of religious teachings. Changes in mindset or perspective then occurred, which previously was oriented to profit only, now turned into fulfilling spiritual needs through business activities. This behavior change is then referred to as behavioral transformation. This transformation is based on personal experiences, internal and external environments, and beliefs in values. This change is seen in the intentions, motivations, and goals in performing their business activities. These conditions change their behavior in running a business. 
The transformation of the meaning of success leads to sincerity in performing business activities and benefits or maslahah. All this stems from a belief in the form of faith and construction of Muslim businessmen behavior based on Islamic values, which are realized in everyday life. Transformation of success meaning for Muslim women entrepreneurs is caused by personal experience, selfdisclosure, internal and external environment, and access to information. The transformation of economic meaning did not change in the sense that the informants maintained business continuity. However, the meaning of non-economic or spiritual aspects is transformed into maslahah; there is no worry and prioritizes the alms. Moreover, non-economic aspects and spiritual journeys underlie Muslim entrepreneurs in achieving business success, as expressed by informant 3 when running with istiqomah (consistent), the door of fortune is opened for her. After undergoing a behavioral transformation, entrepreneurs realized that religious teachings are the main foundation in life, including business.

\section{CONCLUSION AND IMPLICATION}

The life transformation of women entrepreneurs contributes more color and development in the expression of their happiness. The behavior of informants in business management, employee management, and financial management was based on the intention to apply Islamic values. Thus, Islamic values rather than economic interests dominate the behavior of informants. It is based on the spiritual aspect that the informants believe in obtaining the blessing of wealth, pleasure, and mercy from Allah SWT. The instinctive nature of women also underlies the behavior of Muslim entrepreneurs in their business activities, especially in managing employees.

Business success for the informants is not only interpreted as an economic achievement but also an increase in selfquality in the aspect of spirituality. The informants considered the spiritual aspect where religious values construct it. In addition, they also have roles as mothers, wives, and economic actors so that the value of usefulness is highlighted in performing business activities. Muslim women entrepreneurs in Surakarta in implementing Islamic values in their business activities can be observed from three aspects, i.e., aspects of business management, employee management, and financial management. Transformation also occurred in the behavior of Muslim entrepreneurs related to the application of Islamic values in running their businesses. Personal experience experienced by a person, understanding of religious values, and application in business activities cause this transformation.

Muslim women entrepreneurs in Surakarta interpreted their success from two sides. The first is from the perspective of business sustainability. The second is the meaning of success that is not solely from the material/world side but also the ukhrowi (hereafter) standpoint, including the absence of worries and fears, orientation to benefit, and balance between work and family. The meaning of the business's success is through a transformation process to impact the behavior of
Muslim entrepreneurs. The purpose of its business activities leads to broad benefits and can allocate time for roles in the domestic and public sectors.

This research has implications for the theory of producer behavior. As conventional producer behavior theory reveals, producers' motivation is trying to achieve maximum profit for themselves, and these actions are individual and not oriented towards others. However, Muslim women entrepreneurs in achieving satisfaction have an orientation or goal for others. It is because Muslim women entrepreneurs have multiple roles in their lives, namely as mothers, wives, and economic actors. This research is expected to be input and recommendation for policymakers (government) in developing and empowering women entrepreneurs to increase their economic contribution. Each typical female entrepreneur behavior will require different handling and approach. Applying the phenomenological approach in this study allowed us to understand behavior and transformations, especially religious or spiritual phenomena. This approach tends to be better at explaining the phenomenon than an approach that uses cause and effect.

\section{ACKNOWLEDGMENT}

I would like to thank Universitas Sebelas Maret Surakarta for providing support during the research.

\section{REFERENCES}

[1] Akehurst, G., Simarro, E., \& Mas-Tur, A. (2012). Women entrepreneurship in small service firms: Motivations, barriers and performance. The Service Industries Journal, 32(15), 2489-2505. https://doi.org/10.1080/02642069.2012.677834

[2] Alonso, N., \& Trillo, D. (2014). Women, Rural Environment and Entrepreneurship. Procedia - Social and Behavioral Sciences, 161, 149-155. https://doi.org/10.1016/j.sbspro.2014.12.039

[3] Byström, H. (2020). Happiness and Gold Prices. Finance Research Letters, 35, 101599. https://doi.org/10.1016/j.frl.2020.101599

[4] Chin, S. T. S., Raman, K., Yeow, J. A., \& Eze, U. C. (2012). Relationship Between Emotional Intelligence And Spiritual Intelligence In Nurturing Creativity And Innovation Among Successful Entrepreneurs: A Conceptual Framework. Procedia - Social and Behavioral Sciences, 57, 261-267. https://doi.org/10.1016/j.sbspro.2012.09.1184

[5] Clarke, J. S., \& Holt, R. (2019). Images of entrepreneurship: Using drawing to explore entrepreneurial experience. Journal of Business Venturing Insights, 11, e00129. https://doi.org/10.1016/j.jbvi.2019.e00129 
[6] Creswell, J. W. (2010). Research design pendekatan kualitatif, kuantitatif, dan mixed. Yogyakarta: Pustaka Pelajar.

[7] Muro, P., \& Turner, J. R. (2018). Entrepreneurial opportunity pursuit through business model transformation: A project perspective. International Journal of Project Management, 36(7), 968-979. https://doi.org/10.1016/j.ijproman.2018.07.001

[8] Halim, N. A. A., \& Razak, N. A. (2014). Communication Strategies of Women Leaders in Entrepreneurship. Procedia - Social and Behavioral Sciences, 118, 21-28. https://doi.org/10.1016/j.sbspro.2014.02.003

[9] Ismail, V. Y. (2014). The Comparison of Entrepreneurial Competency in Woman Micro-, Small-, and Mediumscale Entrepreneurs. Procedia - Social and Behavioral Sciences, $\quad 115, \quad 175-187$. https://doi.org/10.1016/j.sbspro.2014.02.426

[10] Kaciak, E., \& Welsh, D. H. B. (2020). Women entrepreneurs and work-life interface: The impact of sustainable economies on success. Journal of Business Research, 112, 281-290. https://doi.org/10.1016/j.jbusres.2019.11.073

[11] Lee, W. (2015). Social Capital as a Source of Business Advantages for a Woman Entrepreneur in the Context of Small-size Business. Asian Social Science, 11(12), p155. https://doi.org/10.5539/ass.v11n12p155

[12] Minniti, M. (2010). Female Entrepreneurship and Economic Activity. The European Journal of Development Research, 22(3), 294-312. https://doi.org/10.1057/ejdr.2010.18

[13] Nasir, M., \& Iqbal, R. (2019). Factors Affecting Growth of Women Entrepreneurs in Pakistan. 3(1), 17.

[14] Newbery, R., Lean, J., Moizer, J., \& Haddoud, M. (2018). Entrepreneurial identity formation during the initial entrepreneurial experience: The influence of simulation feedback and existing identity. Journal of Business Research, 85, 51-59. https://doi.org/10.1016/j.jbusres.2017.12.013

[15] Ramadani, V. (2015). The Woman Entrepreneur in Albania: An Exploratory Study on Motivation, Problems and Success Factors. Journal of Balkan and Near Eastern Studies, 17(2), 204-221. https://doi.org/10.1080/19448953.2014.997488

[16] Rosca, E., Agarwal, N., \& Brem, A. (2020). Women entrepreneurs as agents of change: A comparative analysis of social entrepreneurship processes in emerging markets. Technological Forecasting and Social Change, $157, \quad 120067$. https://doi.org/10.1016/j.techfore.2020.120067

[17] Salas-Vallina, A., Alegre, J., \& Fernández Guerrero, R. (2018). Happiness at work in knowledge-intensive contexts: Opening the research agenda. European Research on Management and Business Economics, 24(3), 149-159.

[18] Shastri, D., \& Rao, U. T. (2014). Women Entrepreneurs of Gujarat. Procedia Economics and Finance, 11, 745752. https://doi.org/10.1016/S2212-5671(14)00238-X

[19] Strauss, A., \& Corbin, J. (2003). Penelitian Kualitatif. Yogyakarta: Pustaka Pelajar.

[20] Slavec, A., Drnovšek, M., \& Hisrich, R. D. (2017). Entrepreneurial openness: Concept development and measure validation. European Management Journal, $35(2)$, 211-223. https://doi.org/10.1016/j.emj.2016.09.003

[21] Sørensen, J. F. L. (2021). The rural happiness paradox in developed countries. Social Science Research, 98, 102581. https://doi.org/10.1016/j.ssresearch.2021.102581

[22] Xavier, S. R., Ahmad, S. Z., Nor, L. M., \& Yusof, M. (2012). Women Entrepreneurs: Making A Change from Employment to Small and Medium Business Ownership. Procedia Economics and Finance, 4, 321-334. https://doi.org/10.1016/S2212-5671(12)00347-4

[23] Zeb, A., \& Ihsan, A. (2020). Innovation and the entrepreneurial performance in women-owned small and medium-sized enterprises in Pakistan. Women's Studies International Forum, 79, 102342. https://doi.org/10.1016/j.wsif.2020.102342 